\title{
Discussion on Diversified Financing Channels of Private Colleges and Universities
}

\author{
ZHANG Ming-kai ${ }^{1.2}$, WANG Rong-ming ${ }^{1}$ \\ 1.Oxbridge College,Kunming University of Science and Technology,Kunming 650106, \\ 2.Faculty of Management and Economics, Kunming University of Science and Technology, Kunming 65 \\ 0093
}

Keywords: Private colleges and universities; diversified financing channels

\begin{abstract}
Since the rise of the private education in 1980s, it has got great development, which also has made great contribution to the prosperity of our country's education at the same time. However, the self financing initiatives and the positioning of public welfare has made the development of private colleges and universities be restricted by the lack of finance during the period of development with a large number of constraints, which has derived a lot of problems. This paper discussed the diversified financing channels of private colleges and universities in the new period, putting forward the feasible ways to raise funds, which can have theoretical and practical significance.
\end{abstract}

\section{INTRODUCTION}

The proportion of China's first private university "China Social University" was founded in 1982. Since then, private colleges and universities have went through thirty years of development, until May 2015, according to data released by the Ministry of Education ${ }^{1}$, private colleges and universities of China have reached 722 (including 447 normal independently set-up private universities, 275 independent colleges ), the number of private colleges and universities can be accounted for $25.4 \%$ of the total amount of higher education ( totally 2845), this proportion is increasing year by year. Private colleges and universities plays a more and more important role in the development of higher education in China, but because of the way of the establishment of private colleges and universities is raised by the investors, the subsidy funds by the government is less than public colleges and universities, which at the same time has the nature of public welfare, therefore, the return on investment is relatively lower than the enterprises, thus, it has increased the difficulty of financing, so the most private colleges and universities are facing problems of shortage of funds, the shortage of funds may lead investors take short-sighted behavior, which can cause a series of problems. At first, in this paper, it analyzed the main problems caused by the shortage of funds, so as to illustrate the importance of capital adequacy, putting forward the diversified financing channels, making analysis on the advantages and disadvantages of the different financing channels, making comparison and summary based on the ways of raising funds, at last, pointing out the ways of financing in the future, so as to provide reference for the development of the private colleges and universities as well as the policy guidance of the government.

\section{The Main Problems Caused by the Shortage of Funds in Private Colleges and Universities}

\subsection{Insufficient Potential Development}

The established qualification approval of private colleges and universities is very strict, the initial investment funds should meet the established requirements, at the very beginning, the amount of students is relatively less,generally speaking, the matching requirements are lower and funds are not enough, if the size of the students can reach a certain number,the source of funds that mainly rely on tuition fees from students can also keep the normal operation. But with the continuous expansion of enrollment, the supporting requirements continue to increase, for example, after a

${ }^{1}$ source of data: http://henan.sina.com.cn/edu/jynews/2015-05-22/0850158671.html. 
certain period of development, most of the private colleges and universities face the problems of expanding the school size, increasing the number of buildings, recruiting more staff, investing more hardware and software, therefore, the funding gap is huge under the condition of lacking government funding support, thus, the previous capital can only maintain the normal operation. Therefore, most private colleges and universities face the problem of lacking insufficient potential development.

\subsection{Not Meeting the Required Standard of Running School}

Under the condition of lacking funds as well as no proper financing channels, in order to maintain the school operation, the condition of running school of some private colleges and universities can not meet requirements, for example, with the condition that software and hardware conditions are constant, with the increase of the number of students, the training funds of each student, the area of each student, the matching teacher of each student, as well as the experimental condition of each student will be greatly reduced, which can ultimately affect the students' culturing quality, going far away with the essence of education.

\subsection{The Quality of Training Declined Seriously}

Shortage of funds led to the conditions of running schools can not meet the requirement, which can ultimately affect the quality of culturing the students. Although the reasons for the declining quality of students are many, from the perspective of schools to find the reasons, the lacking condition of running school is the initiative factor that can affect the students. The tuition fees of the private colleges and universities are far higher than public colleges and universities, however, the education condition that the students should share existed a huge gap, the main reason is that the private colleges and universities can not get the supporting funds from the government, the funds of running school mainly rely on the tuition fees, under normal circumstances, $40 \%-50 \%$ of tuition fees are withdrawn by the investor part to make compensate for the investment, then the remaining part is left for running school (as for many private colleges and universities, the proportion of funds that is used to run school may be actually lower in fact), after having distribution, the role for this part of the funds is relatively limited,thus, students are lack of the necessary learning conditions and the quality will naturally be declined, which is similar to the difference between the ordinary high school and the key high school.

\section{Analysis on Diversified Financing Channels of Private Colleges and Universities}

The impact of the shortage of funds on private colleges and universities is huge, therefore, in the new era, the private colleges and universities should actively broaden the financing channels with the use of diversified financing channels, so as to solve the problem of lacking funds.

\subsection{The Income of Tuition Fees}

The income of tuition fees is the main source of funds for private colleges and universities, which can play a crucial role in the survival and development for private colleges and universities, in order to ensure the income of tuition fees to keep the normal operation of schools, the number of students should reach a certain size. Therefore, schools should adopt corresponding measures to ensure the school's reputation and quality, so that the students scale can keep stability in a certain level. Only in this way, the income of tuition fees can get the protection, the funding source of school can be guaranteed. At the beginning of 2014, private colleges and universities in tuition revenue ushered a good opportunity, since many provinces had issued relevant policies, under the premise of civilian run colleges and universities teaching level rating,many governments allow private colleges and universities to raise tuition fees with the amplitude of 1000-5000 Yuan, which can increase school funds at a certain degree. But for students, it is no doubt that it has increased the burden of going to school, which can ultimately affect the enrollment rate, therefore, the income of tuition fees is very essential but which also can have a certain limit and reverse effect.

\subsection{Social Capital}

The social capital here refers to the private capital. The stock of private capital in China is huge, most are in the idle states because there is no suitable investment channels, therefore, private colleges and universities can make use of the idle private capital to make financing, thus the 
characteristics of this way is that the source of funding can be in a wide range with a large amount, which is easily to access relatively, but the problems that mainly existed are as follows: in what kind of way to introduce private capital, What are the rights and status that private capital can share, What is the corresponding return on investment or mortgage financing, After solving these problems, it can be feasible to introduce the social capital. The defects are as follows: the private colleges and universities may sacrifice a part of the benefits, which may pay high cost, or lead to multiple management, resulting in conflicts and so on, therefore, it needs to be analyzed in combination with the specific situation.

\subsection{Direct Financing}

Direct financing mainly refers to issuing the shares of stocks or bonds, thus, the cost of financing is relatively low, but the implementation of the requirement is high. Whether the private colleges and universities can adopt this approach mainly depends on the nature of the investor part, if the investor is a listing corporation, it can use this way to use educational resources as financing products for direct financing,in 2015, there is one domestic investor part of private colleges and universities issued the construction bonds to build up the new campus, whether it is successful or not, it is a good way to guide and expand the financing for private colleges and universities, on one hand, the requirements of this way on the investor part are higher, thus, the majority of private colleges and universities has difficulties in the implementation stage, on the other hand, the direct financing must have investment prospects that can attract investors with investment returns, or with the mortgage assets value, otherwise, this kind of raising funds may fail in the end.

\section{Analysis on Financing Channels in Future}

\subsection{Enterprises Run by Schools}

The enterprise run by school is a kind of company which takes making profits as the purpose by the founder of the school, or the stocks of holding party, in now stage, the enterprises run by public colleges and universities are very common, such as a certain school press or in other various modes, but the amount of enterprises that run by private colleges and universities are very less, in times of national entrepreneurship, it should be better to introduce the corresponding policies to encourage schools to start business, which also should formulate policies to avoid start business blindly, so as to avoid the venture of causing resource waste with the failure of starting business. The enterprises run by school can make private colleges and universities realize self-reliance, namely, relying on their own strength to get financial support, so as to solve the problem of lacking funds, reduce the requirements to the government. In addition, providing conditions for schools to go the road of having application development, thus, students can go to their own school run enterprises to have practical learning, so as to enhance practical ability and enhance the quality of culturing at the same time. As for private colleges and universities, the enterprises run by schools themselves are lack of funds, therefore, it has a certain difficulty in implementing, but the corresponding measures can be explored and discussed.

\subsection{PPP}

PPP is one of the most popular financing models at present, which was originated in UK, which is mainly applicable to the financing of public infrastructure, public goods and services and some public fields. Because the original meaning of PPP is intended to provide cooperation between government and private party. Therefore, private colleges and universities an adopt this mode of application that must take government as the leading factor, which exists difference between using their own strength of financing, the specific operation method needs to be further in-depth study, such as the following problems: how the financing of private universities can make use of PPP. Which aspects can go on with financing. What kind of roles and functions the government should play. Who can execute the right of management after financing in the corresponding fields. How to execute. How to define the subject status of the investor parties, What is the benefit sharing mechanism. How to share the risks as well as many other problems. Here provides a simple idea: the government can lead, some fields of private colleges and universities (such as hardware) can be regarded as the object of financing, both the two parties can agree on the specific details of 
cooperation, so as to absorb social capital to have investment (the private colleges and universities party can also act as one of the main part of the investment, this is very special, which needs to negotiate their position), therefore, the government can play the role of guarantee and supervision indirectly, which can not be directly involved in the management, while the management can be executed by the original private colleges and universities, or the professional education management mechanism that both sides specified. Private colleges and universities can adopt the PPP financing model, which also can be innovative combined with China's national conditions, China has put forward clearly "Colleges and universities should improve multi inputting mechanism, with positive innovation supporting modes, exploring the government and social capital partnership (PPP) mode to attract social investment." Therefore, this kind of approach in future can have vigorously implementing possibility, which should firstly study study the feasibility in theory, so as to design a specific operation method and provide some new ideas for the financing of private colleges and universities, therefore, the research itself has important theoretical and practical value.

\section{Conclusion}

Through the above research, it proposed the following main problems: the insufficient potential development of private colleges and universities because of the lack of funds, the condition of running school is not up to the requirement, and the quality of culturing is seriously declined and so on. Moreover, it put forward six kinds of conventional financing ways in new era, making analysis on the ways of raising funds one by one,pointing out the advantages and disadvantages at the same time, on this basis, discussing on the feasible financing ways in the future. The ideas of this paper has provided the guidance for the private colleges and universities to solve the problem of lacking funds, which has theoretical and practical value. However the future feasible financing way only provides a theoretical framework because of the limited space, therefore, the specific operation method is worthy of more in-depth study.

\section{Reference}

[1]Jiang Min. Discussion on the Financing Mode of Private Universities in China [J]. Financial and Economic Circles(Academic Edition), 2014,19.

[2]Ma Honghong.On Financing Difficulties and Countermeasures of M Private University [J]. Business Manager, 2015,05.

[3]Wang Shuaihong. Research on the Influencing Factors of Financing Strategy of Private University [J]. Scientific and Technological Economy Market, 2015,09.

[4]Tang Zhiwen. The Revelation of Foreign Private Universities Financing Experience to Private Universities of China [J]. Journal of Chang Sha University, 2012,03. 